\title{
Microbiological Quality Assessment of Drinking Water in Lalo Commune, Benin (West Africa)
}

\author{
Roch Christian Johnson ${ }^{1}$, Gratien Boni ${ }^{1}$, Hermione Amoukpo', Yves Barogui ${ }^{2}$, \\ Gabriel Diez ${ }^{3}$, Didier Agossadou', Ghislain Emmanuel Sopoh'², Michel Boko ${ }^{1}$ \\ ${ }^{1}$ Laboratory of Hygiene, Sanitation, Toxicology and Environmental Health, Interfaculty Center of Training and \\ Research in Environment for the Sustainable Development, University of Abomey-Calavi (UAC), Cotonou, Benin \\ ${ }^{2}$ National Buruli Ulcer Control Program, Ministry of Health, Cotonou, Benin \\ ${ }^{3}$ Anesvad Foundation, General Concha, Bilbao, Spain \\ Email: "rochjohnson@yahoo.fr, bonigras@yahoo.fr, amohermy@yahoo.fr, yvesbaro@yahoo.fr, \\ didieragossadou@yahoo.fr, gabrieldiez@anesvad.org, ghislainsop@yahoo.fr, bokomichel@gmail.com
}

Received 8 June 2016; accepted 17 July 2016; published 20 July 2016

Copyright (C) 2016 by authors and Scientific Research Publishing Inc.

This work is licensed under the Creative Commons Attribution International License (CC BY). http://creativecommons.org/licenses/by/4.0/

(c) (i) Open Access

\begin{abstract}
Although drinking water is readily available in Benin, its quality presents a public health concern. The district of Ahomadégbé in the commune of Lalo is characterized by several artesian wells. Unfortunately, anthropogenic factors negatively affect the drinking water quality in this area. The aim of this research was to study the microbiological quality of drinking water in the Ahomadégbé district, and to review household water treatment methods employed by the local population. Thirty-five water samples were taken-at water collection points, at selected points along the water transportation system and from water storage facilities, and microbiological parameters were measured. Qualitative data were collected via in-depth interviews with key informants regarding local household water treatment methods. Results reveal that there is a significant degree of microbiological pollution of drinking water in this district, particularly during the water transportation and storage stages where microbiological pollution exceeds levels approved by the World Health Organization. Local residents are familiar with several household water treatment methods. However, these methods are inconsistently applied, which limits their effectiveness. In addition to improving the quality of the drinking water resource itself, it is important to set up interventions relating to water treatment methods in local households.
\end{abstract}

\section{Keywords}

Benin, Lalo, Microbiological Pollution, Water Treatment

\footnotetext{
*Corresponding author.
}

How to cite this paper: Johnson, R.C., Boni, G., Amoukpo, H., Barogui, Y., Diez, G., Agossadou, D., Sopoh, G.E. and Boko, M. (2016) Microbiological Quality Assessment of Drinking Water in Lalo Commune, Benin (West Africa). Journal of Water Resource and Protection, 8, 816-822. http://dx.doi.org/10.4236/jwarp.2016.88066 


\section{Introduction}

Potable and easily accessible water is essential for good health. Unfortunately, approximately 663 million people worldwide live without access to potable water [1]. Roughly half of these people dwell in Sub-Saharan Africa [1]. Deficient water supply affects population health directly and indirectly-either causing diarrhoeal diseases or resulting in diseases linked to poor personal hygiene [2]. Currently, the majority of diarrhoea-related deaths worldwide are explained by a lack of access to safe drinking water, or a deficiency in personal hygiene [1]. Furthermore, in developing countries, $17 \%$ of all deaths of children below 5 years of age are due to diarrhoea (usually following ingestion of poor quality drinking water) [3] [4]. In Benin, despite efforts to improve the availability and accessibility of potable drinking water (at the time of writing this article, drinking water availability is estimated to be $85.4 \%$ in urban areas and $69.3 \%$ in rural areas [5], problems regarding a lack of access to potable water still arise, particularly in rural and peri-urban settings. Each year, approximately 7000 Beninese people succumb to diarrhoea; and 4300 of these are children under the age of 5 years [6]. These deaths are highly correlated with microbiological pollution of drinking water, and a lack of sanitation and hygiene. They tend to occur primarily in the rural and peri-urban contexts where populations either do not have access to potable water, or have to travel long distances to reach suitable water sources. Apart from the availability of fresh water, the anthropogenic factors associated with the transportation and storage of drinking water also significantly affect its quality. This is certainly the case in the Ahomadégbé district. The aim of this research is to investigate the microbiological quality of drinking water at three important "stages" of the water provision system, i.e., at water collection points, at selected points along the water transportation system and at water storage facilities in the Lalo commune and to review the various household water treatment practices known and used by local residents in the study area.

\section{Methods}

\subsection{Study Area}

The study was carried out in the Lalo commune, in the Ahomadégbé district (Figure 1). The Lalo commune is one of the administrative subdivisions of the department of Couffo in Benin. The Ahomadégbé district comprises four villages: Aloya, Ahomadegbe centre, Hangnonhoué and Adjaïgbonou. Its population is estimated at 5257 residents.

\subsection{Research Design}

This study comprises two parts, i.e. a laboratory analysis of drinking water samples to determine the degree of microbiological pollution present at water source points, in the water transportation system, water storage facilities, and a qualitative study based on anecdotal, interview-derived data intended to document the household water treatment methods employed by residents in the study area.

\subsection{Microbiological Analysis of Drinking Water}

\subsubsection{Sampling}

Water samples were collected in sterile $500-\mathrm{mL}$ bottles as follows:

- 17 sterile 500-mL bottles at points where water is collected by residents, i.e. at the human-powered borehole, from artesian wells, from drilling, from rain tanks and from favoured collection points along the river bank;

- 08 sterile $500-\mathrm{mL}$ bottles from containers used to transport water from the collection points listed above to the village, on average 1 to 2 kilometres;

- 10 sterile $500-\mathrm{mL}$ bottles from water storage receptacles in personal residences in the village.

The bottles of taking water samples were filled to the three quarter.

Further details regarding the number of samples and the sample sites are summarized in Table 1.

\subsubsection{Transport to Laboratory}

The sterile 500-ml sample bottles were carefully numbered and labelled. Samples were transported to the Laboratory of Hygiene, Sanitation, Toxicology and Environmental Health, Interfaculty Center of Training and Research in Environment for the Sustainable Development, University of Abomey-Calavi in a cooler at $4^{\circ} \mathrm{C}$. The 


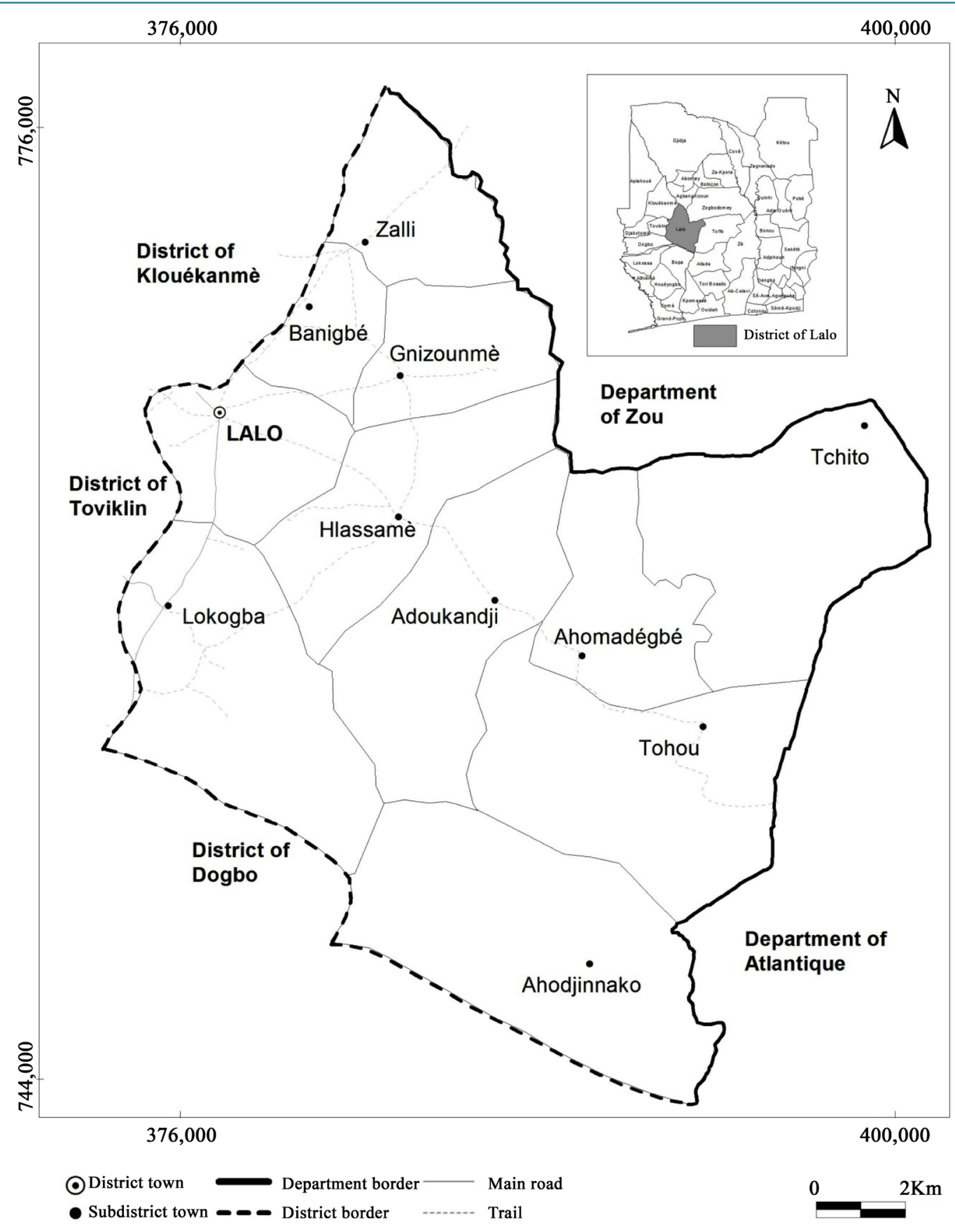

Source: IGN, 1992

Réalisation: Fsaï ANAGONOI

Figure 1. Map of study area.

Table 1. Water sample sites.

\begin{tabular}{|c|c|c|c|c|}
\hline & Sources & Transport & Storage & Totals \\
\hline Human-powered borehole, Artesian wells, Drilling & 12 & 06 & 06 & 24 \\
\hline Surface water (river) & 02 & 02 & 02 & 06 \\
\hline Raintank water & 03 & 00 & 02 & 05 \\
\hline Totals & 17 & 08 & 10 & 35 \\
\hline
\end{tabular}


displacement of the water samples of Ahomadégbé at the laboratory was made in the car and distance covered is approximately 150 kilometers. Once in the laboratory, samples were preserved in a refrigerator.

\subsubsection{Laboratory Analysis}

Bacteriological analysis was performed in two steps:

1) Membrane filtration: $100 \mathrm{ml}$ of each sample was filtered with certified $0.45 \mu \mathrm{m}$ membrane for microbiological analysis which is hydrophilic mixed cellulose esters, and the membrane incubated on a specific medium.

2) Different media and incubation conditions (time and temperature) were used depending on the type of faecal bacteria sought. The result is expressed as colony forming units (CFU) per unit volume. The specific media used for the enumeration of coliforms in this study were the middle Rapid'E Coli medium (for coliforms) and the Slanetz/Bartley medium (for faecal streptococci). Total coliform colonies were enumerated after the petri plates had been incubated at $37^{\circ} \mathrm{C}$ for $24 \mathrm{~h}$. The enumeration of faecal coliforms and E. coli was done after incubation at $44^{\circ} \mathrm{C}$ for $24 \mathrm{~h}$. The enumeration of faecal streptococci was done after incubation at $37^{\circ} \mathrm{C}$ for 48 h. [7].

\subsubsection{Qualitative Study}

For the qualitative component of this study, $10 \mathrm{key}$ informants were selected for in-depth interviews. Women from the various villages were assembled in groups. The presidents of the 10 most active groups of the locality were selected as respondents. An experienced social scientist moderated all of the in-depth interviews. In addition to handwritten notes taken by the interviewer, all interviews were tape-recorded and later transcribed and translated from the local language into French. The main issue addressed during the in-depth interviews was that of water treatment methods employed in individual homes in the area. Privacy and confidentiality of the respondents, as well as good relations between these individuals and the interviewer were maintained at all times during the research process. The questions were designed not to affect the morale or personality of study subjects and were administered after respondents had been given an explanation of the research, what they were required to do. They were informed that their involvement in the process was voluntary.

\subsection{Operational Definitions}

Based on the water sanitation and hygiene (WASH) report [1], unimproved (poor) water is defined as water that is either from a dam or pool, or is stagnant in a river, stream or rainwater tank. Improved (good) water, however, includes water piped into residences, water from boreholes or water towers, and water from artesian wells.

\subsection{Ethical Considerations}

Ethical clearance for this research was obtained from the National Ethical Review Board of the Ministry of Health in Benin (Authorization $\mathrm{N}^{\circ} 147 / \mathrm{MS} / \mathrm{DC} / \mathrm{SGM} / \mathrm{DFRS} / \mathrm{CNPERS/SA).} \mathrm{The} \mathrm{questions} \mathrm{for} \mathrm{the} \mathrm{in-depth} \mathrm{in-}$ terviews were proven not to affect the morale or personality of study subjects. Oral informed consent was obtained from each participant after they had been given an explanation of the research and what they were required to do and had been informed that their involvement in the process was voluntary.

\section{Results}

\subsection{Microbiological Analyses}

The microbiological parameters assessed for each water sample, along with results, are presented in Tables 2-4.

As one might expect, there is significant faecal contamination present in surface and rainwater tanks. The microbiological quality of samples from improved water sources is acceptable.

The samples collected from transport vessels show that contamination of the water resource begins during this phase of water handling.

Table 4 shows that water storage facilities are a significant source of faecal contamination.

\subsection{Water Treatment Methods Employed by Local Residents}

Several water treatment methods are employed in individual households. The three main "approaches" to home 
Table 2. Microbiological analysis results for samples collected at source points.

\begin{tabular}{ccccccc}
\hline Parameters & Artesian wells & boreholes & Drilling & Rainwater & Surface water & Standards WHO \\
\hline E. coli & $0 / 100 \mathrm{ml}$ & $0 / 100 \mathrm{ml}$ & $0 / 100 \mathrm{ml}$ & $127 / 100 \mathrm{ml}$ & $220 / 100 \mathrm{ml}$ & $0 / 100 \mathrm{ml}$ \\
Fecal coliforms & $0 / 100 \mathrm{ml}$ & $0 / 100 \mathrm{ml}$ & $27 / 100 \mathrm{ml}$ & $320 / 100 \mathrm{ml}$ & $520 / 100 \mathrm{ml}$ & $0 / 100 \mathrm{ml}$ \\
Total coliforms & $0 / 100 \mathrm{ml}$ & $3 / 100 \mathrm{ml}$ & $737 / 100 \mathrm{ml}$ & $1600 / 100 \mathrm{ml}$ & $5325 / 100 \mathrm{ml}$ & $0 / 100 \mathrm{ml}$ \\
Fecal streptococci & $0 / 100 \mathrm{ml}$ & $0 / 100 \mathrm{ml}$ & $0 / 100 \mathrm{ml}$ & $127 / 100 \mathrm{ml}$ & $175 / 100 \mathrm{ml}$ & $0 / 100 \mathrm{ml}$ \\
\hline
\end{tabular}

Table 3. Microbiological analysis results for water samples collected from transport vessels.

\begin{tabular}{|c|c|c|c|c|c|}
\hline Parameters & Artesian wells & Boreholes & Drilling & Surface water & Standards WHO \\
\hline E. coli & $2 / 100 \mathrm{ml}$ & $95 / 100 \mathrm{ml}$ & $80 / 100 \mathrm{ml}$ & $860 / 100 \mathrm{ml}$ & $0 / 100 \mathrm{ml}$ \\
\hline Fecal coliforms & $7 / 100 \mathrm{ml}$ & $110 / 100 \mathrm{ml}$ & $320 / 100 \mathrm{ml}$ & $1530 / 100 \mathrm{ml}$ & $0 / 100 \mathrm{ml}$ \\
\hline Total coliforms & $2327 / 100 \mathrm{ml}$ & $1700 / 100 \mathrm{ml}$ & $9825 / 100 \mathrm{ml}$ & $11700 / 100 \mathrm{ml}$ & $0 / 100 \mathrm{ml}$ \\
\hline Fecal streptococci & $1 / 100 \mathrm{ml}$ & $151 / 100 \mathrm{ml}$ & $401 / 100 \mathrm{ml}$ & $600 / 100 \mathrm{ml}$ & $0 / 100 \mathrm{ml}$ \\
\hline
\end{tabular}

Table 4. Microbiological analysis results for samples collected at water storage points.

\begin{tabular}{ccccccc}
\hline Parameters & Artesian wells & Boreholes & Drilling & Rainwater & Surface water & Standards WHO \\
\hline E. coli & $2000 / 100 \mathrm{ml}$ & $2280 / 100 \mathrm{ml}$ & $2800 / 100 \mathrm{ml}$ & $220 / 100 \mathrm{ml}$ & $7320 / 100 \mathrm{ml}$ & $0 / 100 \mathrm{ml}$ \\
Fecal coliforms & $2190 / 100 \mathrm{ml}$ & $3300 / 100 \mathrm{ml}$ & $4120 / 100 \mathrm{ml}$ & $470 / 100 \mathrm{ml}$ & $11780 / 100 \mathrm{ml}$ \\
Total coliforms & $14904 / 100 \mathrm{ml}$ & $4375 / 100 \mathrm{ml}$ & $10650 / 100 \mathrm{ml}$ & $1950 / 100 \mathrm{ml}$ & $44600 / 100 \mathrm{ml}$ & $0 / 100 \mathrm{ml}$ \\
Fecal streptococci & $33900 / 100 \mathrm{ml}$ & $32025 / 100 \mathrm{ml}$ & $625 / 100 \mathrm{ml}$ & $275 / 100 \mathrm{ml}$ & $875 / 100 \mathrm{ml}$ & $0 / 100 \mathrm{ml}$ \\
\hline
\end{tabular}

water treatment are:

- Sedimentation, which allows solid particulate matter to settle out of water before use;

- Filtration, which is a further step in removing larger micro-organisms and solid particles from drinking water by passing the water through a porous medium;

- Disinfection, which aims to kill micro-organisms present in drinking water.

These three approaches are complementary according to interviewees: sedimentation removes larger particulate matter from heavily polluted water, filtration removes finer particles that do not settle out during sedimentation, and disinfection eliminates micro-organisms that remain following both the sedimentation and filtration processes.

The specific water treatment technologies employed by different households vary significantly.

The most common sedimentation techniques employed are the addition of aluminium sulphate $\left(\mathrm{Al}_{2} \mathrm{SO}_{4}\right.$, also called alum), and the addition of the leaves of the Moringa plant (Moringa oleifera), a commonly occurring tree in rural areas, the use of which is reported by several authors (e.g., [8]). Residents also use oil, and lemon (Citrus limon) and palm tree (Elaeis guineensis) leaves. These substances are mixed with the water to be treated for several minutes prior to the use.

With regard to filtration, the effectiveness of filters is directly related to the size of their pores, the amount of water filtered through them, and the properties of the water being treated. The commonly used ceramic filters (called songhai in Benin) constitute an effective method despite the problem of their slow filtration rate, limiting their use. Fine cloth is also commonly employed as a filter, especially when water turbidity is high, as is often the case during the treatment of surface water.

Disinfection is most commonly achieved chemically by the addition of dichloroisocyanurate of sodium (DCCNa) tablets (e.g., Aquatabs ${ }^{\circledR}$ ) to water after sedimentation and filtration. However, the availability of these tablets is often limited. Solar disinfection (commonly called SODIS) methods are still relatively unknown amongst local communities, but have great potential in this context as they are cost effective and simple to implement.

\section{Discussion}

Microbiological analyses of the collected samples revealed significant variation with regard to microbiological 
parameters for samples collected at different points in the water supply network. Generally, at the source, water quality was satisfactory. Conversely, the water collected at the only drilling in Adjaïgbonou was already polluted at the source.

The results of the microbiological analyses are upheld by residents' anecdotal reports, e.g., the report that "when it rains, the water in the drilling is red and sometimes contains worms". The same report was obtained for other settlements in the Lalo commune, e.g., in the village of Goveta, in the Tohou district, this issue forces households to use cistern water (rainwater) as drinking water [9]. It is common in poor countries for the water supplied by water distribution systems to be of poor quality [10]. Thus, even though access to so-called "improved water" is good, the quality of this resource often constitutes a significant problem.

Water sources are not always close to households. People often have to travel a significant distance between a water source and their homes. This transportation process often introduces faecal contamination into drinking water due to the use of contaminated containers for water transportation. Indeed, the microbiological analyses revealed a significant increase in contamination levels during water transportation by residents in the study area. This contamination may be explained by several factors such as poor maintenance and sanitation of water transport containers, a failure to cover these containers during water portage (or the use of tree leaves for this purpose), and a lack of personal hygiene (especially hand hygiene) on the part of water collectors.

Along with water transportation, storage of drinking water by local residents also constitutes a significant source of faecal contamination. Water taken from artesian wells and boreholes, which was found to be free of faecal coliforms and E. coli, was later found to contain high levels of faecal pollution (once this water was being stored in homes). This contamination is probably due to several factors including the failure to cover water storage containers, poorly sanitized bailing cups, and risky behaviour such as not washing hands before contact with the water.

The results obtained during this study are similar to those obtained in other regions of Benin, e.g., the municipality of Sèmè-Kpodji, another semi-urban municipality, where the microbiological quality of water consumed at the household level is highly polluted, largely due to defective water transportation and storage [11]. Other studies have further confirmed that transportation and storage of water in rural contexts promote the process of microbial contamination (e.g. [12]-[15]).

Like several other studies, this research has confirmed that interventions aimed simply at increasing accessibility to "improved water" are not sufficient to reduce the risks related to drinking water contamination. As asserted by Clasen et al., it is also vital to implement interventions at the household level. The latter form of intervention is estimated to be twice as effective in diarrhoea prevention as the former [4]. Qualitative anecdotal data suggest that local residents have the knowledge necessary to implement effective home water treatment strategies. However, a lack of systematic implementation of this knowledge is curbing the effectiveness of these methods at the household level. This study remains a rapid assessment of the knowledge of local residents in the area of household water treatment methods. It is therefore important to more study the knowledge but also the local practices on household water treatment methods to establish coherent home water treatment programmes, adapted to local conditions, to mitigate the effects of the microbiological contamination levels observed in this study.

\section{Conclusion}

Despite the relatively high availability of improved water sources in the study area, this study reveals that contamination often occurs when water is collected from source points, transported from these points to individual households, and stored in these households. To significantly reduce the risks associated within gestion of contaminated drinking water, it is essential that interventions be implemented in this community and others with respect to implementation of effective water treatment methods at the household level.

\section{Acknowledgements}

We are very grateful to the populations of the district of Lalo and the health staff of the CDTUB. We are thankful to the Anesvad Foundation for partially supporting the field work.

\section{Conflict of Interests}

The authors declare that they have no competing interests. 


\section{Authors' Contributions}

RCJ contributed to the data collection, study methodology, and data analysis sections, as well as writing the manuscript; YB, GES GB DA GA and HA all contributed to the literature review and data analysis; MB contributed to the literature review and manuscript editing. All of the authors read and approved the final manuscript.

\section{References}

[1] WHO/UNICEF (2015) Progress on Sanitation and Drinking Water. Rapport-OMS/UNICEF, 2015, 90 p.

[2] Hunter, P., MacDonald, A.M. and Carter, R.C. (2010) Water Supply and Health. PLoS Medicine, 7, 1-9. http://dx.doi.org/10.1371/journal.pmed.1000361

[3] Prüss, A. and Havelaar, A. (2001) The Global Burden of Disease: Study and Applications in Water, Sanitation and Hygiene. In: Fewtrell, L. and Bartram, J., Eds., Water Quality: Guidelines, Standards and Health, Risk Assessment and Management for Water-Related Infectious Disease, IWA Publishing, London, 43-59.

[4] Clasen, T., Schmidt, W.P., Rabie, T., Roberts, I. and Cairncross, S. (2007) Interventions to Improve Water Quality for Preventing Diarrhoea: Systematic Review and Meta-Analysis. BMJ, 334, 782-785. http://dx.doi.org/10.1136/bmj.39118.489931.BE

[5] Ministère du Développement, de l'Analyse Économique et de la Prospective (MDAEP) (2013) CADRE d'accélération des OMD: Accès à l'eau potable et à l'assainissement de base. $112 \mathrm{p}$.

[6] WSP (2012) Impacts Économiques d'un Mauvais Assainissement en Afrique: Le Bénin perd 52 milliards XOF chaque année à cause d'un mauvais assainissement 2012 [consulté le 16 décembre 2014]. www.wsp.org

[7] Rodier, J., Legube, B., Merlet, N., et al. (2009) L'analyse de l'eau. 9ème édition, Dunod, Paris, 1579 p.

[8] Moubokounou, G.L. (2010) Techniques de traitement de l'eau à domicile: Évaluation de l'efficacité des filtres en céramique. Mémoire de master en Ingénierie de l'eau, option : Eau non publié, 2IE, Ouagadougou.

[9] Houndonougbo, M. (2014) Current Situation of Hygiene and Sanitation in the Commune of Lalo in Benin in 2013. Master Thesis in Environment and Health Unpublished, CIFRED/University of Abomey-Calavi, Benin. (In French)

[10] Bartram, J. and Cairncross, S. (2010) Hygiene, Sanitation, and Water: Forgotten Foundations of Health. PLoS Medicine, 7, e1000367. http://dx.doi.org/10.1371/journal.pmed.1000367

[11] Johnson, R.C., Segla, H., Dougnon, T.V., Boni, G., Bankole, H.S., Houssou, C. and Boko, M. (2014) Situation of Water, Hygiene and Sanitation in a Peri-Urban Area in Benin, West Africa: The Case of Sèmè-Podji. Journal of Environmental Protection, 5, 1277-1283. http://dx.doi.org/10.4236/jep.2014.512121

[12] Dikassa, L., Mock, N., Magnani, R., Rice, J., Abdoh, A., Mercer, D. and Bertrand, W. (1993) Maternal Behavioural Risk Factors for Severe Childhood Diarrhoeal Disease in Kinshasa. International Journal of Epidemiology, 22, 327333. http://dx.doi.org/10.1093/ije/22.2.327

[13] Gentilini, M. and Viens, P. (1993) Tropical Communicable Diseases. Eurotext, Paris, 132 p.

[14] Gil, A., Lanata, C., Kleinau, E. and Penny, M. (2004) Children's Faeces Disposal Practices in Developing Countries and Interventions to Prevent Diarrheal Diseases. A Literature Review. Environmental Health Project, U.S. Agency for International Development, Washington DC, $67 \mathrm{p}$.

[15] Judah, G., Donachie, P., Cobb, E., Schmidt, W., Holland, M. and Curtis, V. (2009) Dirty Hands: Bacteria of Faecal Origin on Commuter's Hands. Epidemiology and Infection, 138, 409-414. http://dx.doi.org/10.1017/S0950268809990641 


\section{Submit or recommend next manuscript to SCIRP and we will provide best service for you:}

Accepting pre-submission inquiries through Email, Facebook, LinkedIn, Twitter, etc.

A wide selection of journals (inclusive of 9 subjects, more than 200 journals)

Providing 24-hour high-quality service

User-friendly online submission system

Fair and swift peer-review system

Efficient typesetting and proofreading procedure

Display of the result of downloads and visits, as well as the number of cited articles

Maximum dissemination of your research work

Submit your manuscript at: http://papersubmission.scirp.org/ 